\title{
Determination of Lactulose and Furosine Formation in Heated Milk as a Milk Quality Indicator
}

\author{
Young-Hee Cho', Sung-Moon Hong, and Cheol-Hyun Kim* \\ Department of Animal Resources Science, Dankook University, Cheonan 330-714, Korea \\ ${ }^{1}$ Danone Korea R\&I Center, Seoul 136-701, Korea
}

\begin{abstract}
During heat treatment and storage of milk, deteriorative reaction takes place, which consequently influence on the milk quality. In this study, formation of lactulose and furosine under different thermal conditions and storage conditions, and the ratio of lactulose and furosine (LU/FU) in presence of reconstituted milk powder were determined to establish chemical indicators for heat damages of milk and the adulteration of fresh milk in dairy field. The lactulose and furosine contents linearly increased with increased heating temperature and heating time. It showed high correlation between the formation of lactulose and furosine, and the treatment temperature and time $(p<0.05)$. The lactulose and furosine concentration of HTST milk and UHT milk noticeably increased during storage at $30^{\circ} \mathrm{C}$, but there was no noticeable increase of lactulose and furosine concentration at lower storage temperature. In the raw milk, the lactulose and furosine contents greatly increased with the addition of reconstituted milk. The increase level of furosine was much higher than that of lactulose, which consequently resulted in the lower LU/FU ratio in milk as increase of added reconstituted milk amounts. As comparing with raw milk, there was more than twice reduction in LU/FU ratios after the addition of reconstituted milk $(p<0.05)$. It can be concluded that lactulose and furosine are suitable milk quality indicators of heat damage and for demonstrating improper addition of reconstituted milk powder.
\end{abstract}

Key words: lactulose, furosine, chemical indicator, milk quality

\section{Introduction}

Heat treatment of milk is an essential process in the dairy industry. It results in many chemical and structural changes in milk, the extent of which depends on the temperature and duration of heating (Kulmyrzaev and Dufour, 2002). Mainly two types of chemical reactions may be used to evaluate heat damage: 1) the degradation, denaturation, and inactivation of a heat-labile component, such as whey protein or enzymes, 2) the formation of new substances, such as lactulose hydroxymethylfurfural (HMF) or furosine (Mortier et al., 2000). Applications of these thermal indicators deal mainly with processing optimization, heat load evaluation and identification of limiting values of thermal damage (Pellegrino et al., 1995).

The formation of lactulose and furosine in heated milk products has been revealed further by its identification in

\footnotetext{
*Corresponding author: Cheol-Hyun Kim, Department of Animal Resources Science, Dankook University, Cheonan 330-714, Korea. Tel: 82-41-550-3652, Fax: 82-41-550-3604, E-mail: hichkim@, dankook.ac.kr
}

sterilized milk, commercial evaporated milk and deteriorated dried skim milk (Akalin and Gonc, 1997; Andrews, 1984; Delgado et al., 1992; Pellegrino et al., 1995). The lactulose and furosine values describe the extent of lactose isomerization and early Maillard reaction, respectively. The formation of lactulose in heated milks is due to the alkaline isomerization of lactose catalyzed by the free amino groups of casein (De Block et al., 1996). Furosine is an amino acid formed during acid hydrolysis of the Amadori compound fructosyl-lysine, lactulosyllysine and maltulosyl-lysine produced by the reaction of $\varepsilon$-amino groups of lysine with glucose, lactose and maltose, respectively (Guerra-Hernandez and Corzo, 1996; Guerra-Hernandez et al., 1999). Therefore, this amino acid has been used to measure the early stages of Maillard reaction, not only in foods, but also in biological samples (Guerra-Hernandez et al., 1999). Both reactions have different extents depending on process condition (De Rafael, 1997; Hewedy et al., 1994).

Isomerization of lactose is the predominant reaction during heat treatment of milk; however, the Maillard reaction is more noticeable than lactose isomerization during 
storage of reconstituted milk (Corzo et al., 1994; Resmini and Pellegrino, 1994). Other study (Hurrell et al., 1983) has also reported that the lactulose concentration of the UHT milk was considerably higher than in nonfat dry milks. However, most of the UHT milk samples showed furosine concentration much lower than those of nonfat dry milk; this is because the extent of the Maillard reaction depends not only on the time and temperature of storage but also on the moisture content and the composition of the product. Therefore, the combination of lactulose and furosine values also provides information on the quality and genuineness of commercial milks, particularly to detect the presence of reconstituted milk in consumption milk (Kulmyrzaev and Dufour, 2002).

In this study, the effect of heat treatment conditions and storage conditions on the formation of lactulose and furosine were determined to establish chemical indicators in heat treated milk. In addition, the ratio of lactulose and furosine (LU/FU) was analyzed to study limitation of detection as a quality indicator for the adulteration of fresh milk by adding reconstituted milk.

\section{Materials and Methods}

\section{Sample preparation}

Raw milk was provided from Seoul F\&B (Korea). Three different types of samples were prepared as follows: 1) For the determination of $\mathrm{LU}$ and $\mathrm{FU}$ formation during heat treatments, in-batch heated milk samples were prepared that is, raw milk was sealed in a glass tube and heated in an oil bath (heating at $75^{\circ} \mathrm{C}$ for 10 to $120 \mathrm{~s}$ or heating at $130^{\circ} \mathrm{C}$ for 2 to $\left.60 \mathrm{~s}\right) .2$ ) For the storage test, HTST $\left(75^{\circ} \mathrm{C} / 15\right.$ s) milk and UHT $\left(130^{\circ} \mathrm{C} / 2-3\right.$ s) milk were produced at the pilot plant of Seoul F\&B. These samples were stored at 4 (optimal storage temperature), 10 (storage temperature at stores) and $30^{\circ} \mathrm{C}$ (harsh storage condition) for $4 \mathrm{wk}$ and analyzed at $7 \mathrm{~d}$ intervals. 3) For the study on adulteration of fresh milk by adding reconstituted milk, the reconstituted milk with $10 \%$ total solids was added to fresh raw milk at the ratios of 10,20 and $30 \%$.

\section{Lactulose determination}

Sample preparation for HPLC analysis was carried out by following the methods described by FIL-IDF reference methods (IDF, 1991).

HPLC grade chemicals and distilled-deionized water were used throughout the experiments. Lactulose content was determined by HP 1100 series HPLC system (Hewlett
Packard Co., USA). The system was equipped with a binary solvent management system, an auto injector and auto sampler, thermally controlled column compartment and a refractive index detector. The column used was carbohydrate BC-100 (Benson polymeric, Inc., USA) packed with sulphonic ion-exchanger in the lead form. The column temperature was maintained at $90^{\circ} \mathrm{C}$ and the mobile phase used was distilled-deionized water. The flow rate was maintained at $0.4 \mathrm{~mL} / \mathrm{min}$. Calibration curves were made with standard lactulose (Sigma, USA).

\section{Furosine determination}

One milliliter of sample was hydrolyzed in $8 \mathrm{~L}$ of $8 \mathrm{~N}$ $\mathrm{HCl}$ at $110^{\circ} \mathrm{C}$ for $23 \mathrm{~h}$ in sealed tubes. Nitrogen gas was bubbled through the solution. The hydrolysate was evaporated and the dried sample was dissolved in $0.5 \mathrm{~L}$ water. This solution was passed through a pre-wetted Sep-pak $\mathrm{C}_{18}$ cartridge (Waters Co., USA) and washed with $4.5 \mathrm{~mL}$ water:acetonitrle:formic acid (95:5:0.2). Furosine content was quantified by HP 1100 series HPLC system (Hewlett Packard Co., USA) according to the method of Delgado et al. (1992). The column used was spherisorb ODS2 (octadecylsilane) $5 \mu \mathrm{m}$ column $(0.46 \times 25 \mathrm{~cm}$, Waters Co., USA) operating at ambient temperature. The mobile phase consisted of a solution of $5 \mathrm{mM}$ sodium heptanesul-phonate with $20 \%$ acetonitrile as organic modifier and $0.2 \%$ formic acid. Flow rate was maintained at $1.2 \mathrm{~mL} / \mathrm{min}$ and the UV detector was set at $280 \mathrm{~nm}$. Calibration curves were made with standard furosine, which was purchased from Neosystem (Strasbourg, France).

\section{Results and Discussion}

\section{Changes of lactulose and furosine during heat treatment of milk}

Today a wide range of time/temperature conditions is used for industrial milk sterilization (Akalin and Gonc, 1997). The formation of lactulose and furosine under various thermal process conditions using different combination of heat temperature and time are determined (Tables 1 and 2). As treatment time changed, lactulose and furosine in milk treated at $75^{\circ} \mathrm{C}$ ranged from 1.61 to $2.96 \mathrm{mg} /$ $100 \mathrm{~mL}$ and from 0.37 to $1.69 \mathrm{mg} / 100 \mathrm{~mL}$, respectively. For the milk treated at $130^{\circ} \mathrm{C}$, lactulose and furosine concentrations ranged from 9.29 to $26.60 \mathrm{mg} / 100 \mathrm{~mL}$ and from 2.16 to $7.58 \mathrm{mg} / 100 \mathrm{~mL}$, respectively. The milk treated at $75^{\circ} \mathrm{C}$ showed lower lactulose and furosine values than milk treated at $130^{\circ} \mathrm{C}$. There were statistically significant differences $(p<0.05)$ between temperatures and treatment 
Table 1. Lactulose and furosine formation during heat treatment in oil bath at $75^{\circ} \mathrm{C}$ for various time

\begin{tabular}{cccc}
\hline \hline $\begin{array}{c}\text { Temp. } \\
\left({ }^{\circ} \mathrm{C}\right)\end{array}$ & $\begin{array}{c}\text { Time } \\
(\mathrm{s})\end{array}$ & $\begin{array}{c}\text { Lactulose } \\
(\mathrm{mg} / 100 \mathrm{~mL})\end{array}$ & $\begin{array}{c}\text { Furosine } \\
(\mathrm{mg} / 100 \mathrm{~mL})\end{array}$ \\
\hline \multirow{3}{*}{75} & 10 & $1.613 \pm 0.031^{\mathrm{d}}$ & $0.370 \pm 0.065^{\mathrm{c}}$ \\
& 30 & $1.917 \pm 0.025^{\mathrm{c}}$ & $0.570 \pm 0.127^{\mathrm{c}}$ \\
& 60 & $2.237 \pm 0.125^{\mathrm{b}}$ & $1.061 \pm 0.055^{\mathrm{b}}$ \\
& 120 & $2.960 \pm 0.066^{\mathrm{a}}$ & $1.692 \pm 0.195^{\mathrm{a}}$ \\
\hline
\end{tabular}

${ }^{1)}$ All values are mean $\pm \mathrm{SD}$ of three replicates.

${ }^{\mathrm{a}-\mathrm{d}}$ Means within a column with the same letter are not significantly different $(p<0.05)$.

Table 2. Lactulose and furosine formation during heat treatment in oil bath at $130^{\circ} \mathrm{C}$ for various time

\begin{tabular}{cccc}
\hline \hline $\begin{array}{c}\text { Temp. } \\
\left({ }^{\circ} \mathrm{C}\right)\end{array}$ & $\begin{array}{c}\text { Time } \\
(\mathrm{s})\end{array}$ & $\begin{array}{c}\text { Lactulose } \\
(\mathrm{mg} / 100 \mathrm{~mL})\end{array}$ & $\begin{array}{c}\text { Furosine } \\
(\mathrm{mg} / 100 \mathrm{~mL})\end{array}$ \\
\hline & 2 & $9.290 \pm 0.062^{\mathrm{d}}$ & $2.164 \pm 0.373^{\mathrm{b}}$ \\
130 & 30 & $11.433 \pm 0.344^{\mathrm{c}}$ & $4.429 \pm 0.299^{\mathrm{b}}$ \\
& 60 & $18.450 \pm 1.067^{\mathrm{b}}$ & $6.036 \pm 0.178^{\mathrm{a}}$ \\
& 120 & $26.603 \pm 1.495^{\mathrm{a}}$ & $7.477 \pm 0.219^{\mathrm{a}}$ \\
\hline
\end{tabular}

${ }^{1)}$ All values are mean \pm SD of three replicates.

${ }^{\mathrm{a}-\mathrm{d}}$ Means within a column with the same letter are not significantly different $(p<0.05)$.

time within same temperature. Several studies (Kulmyrzaev and Dufour, 2002; Montilla and Olano, 1997; Resmini and Pellegrino, 1994) have also reported that the amount of lactulose and furosine can be related to the heating conditions mainly time and temperature of the process and product moisture.

As comparing the concentration of lactulose and furosine formed during heat treatment, lactulose formation is much higher than furosine in all samples. Several researchers (Montilla and Olano, 1997; Pellegrino et al., 1995; Resmini and Pellegrino, 1994) have also indicated that the heat-treated milks normally show lower increase values of the furosine than the lactulose. In the studies by De Rafael et al. (1997), the kinetics of the lactose isomerization and early Maillard reaction occurring in sterilized milk processed under experimental laboratory conditions were compared. The authors showed that in the temperature range $110-150^{\circ} \mathrm{C}$ and holding times of $10-50 \mathrm{~s}$, the amount of isomerized lactose is always much higher than that of lactose in the early Maillard reaction. Good correlation has been found between those parameters in milk samples processed under laboratory conditions.

\section{Changes of lactulose and furosine during storage of heat treated milk}

Changes in the lactulose and furosine concentration in HTST milk and UHT milk produced at a pilot plant are

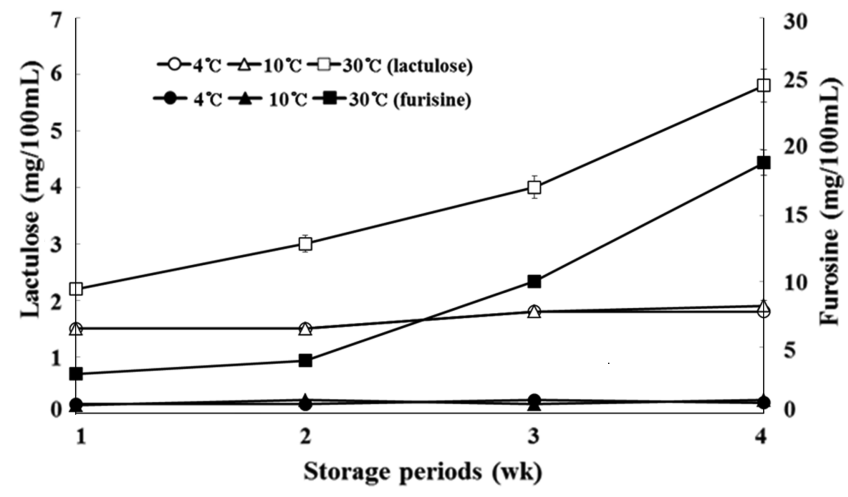

Fig. 1. Changes of lactulose and furosine content in HTST treated milk during storage at various temperature.

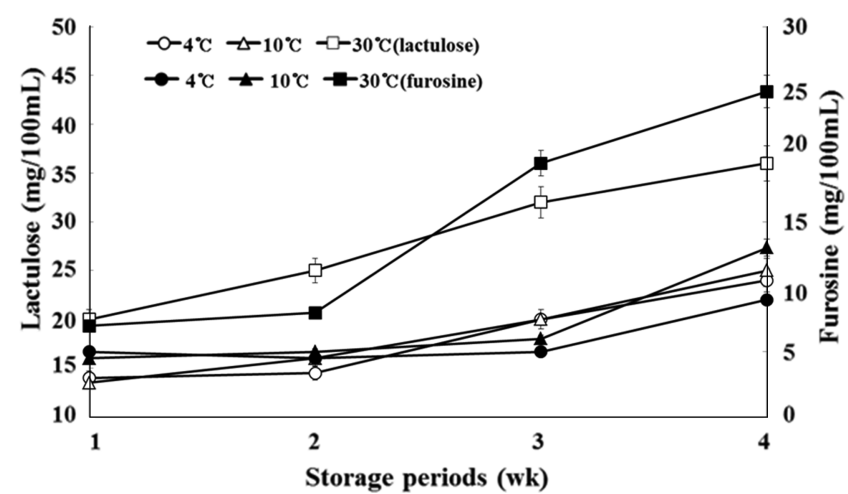

Fig. 2. Changes of lactulose and furosine content in UHT reated milk during storage at various temperature.

observed during storage at different temperatures (Figs. 1 and 2). Average increases in concentrations of these two compounds are highly dependent on the storage temperature that is, the concentrations of lactulose and furosine in both samples noticeably increased only at $35^{\circ} \mathrm{C}$. On the other hand, HTST milk and UHT milk showed different results at lower storage temperatures $\left(4\right.$ and $\left.10^{\circ} \mathrm{C}\right)$. The lactulose and furosine concentrations in UHT milk steadily increased through storage periods, while those in HTST milk remained constant.

The increase rate of furosine was higher than lactulose in all samples. Corzo et al. (1994) and Pellegrino et al. (1995) have reported that the early Maillard reaction is more noticeably increased than lactose isomerization is during storage of UHT milk.

With these results, it can be concluded that there was a clear relationship between the storage periods and temperature, and the lactulose and furosine values $(p<0.05)$.

\section{Changes of lactulose and furosine in the presence of reconstituted milk}

Reconstituted milk is added to raw milk to reduce the 
cost because of the cheap price of commercial milk powder. During the manufacturing process of milk powder, such as heating and spray drying, the structure of milk proteins can change and some of milk nutrient can be damaged. Thus, addition of milk powder to milk will reduce the nutritional and component properties of milk (Lan et al., 2010)

Table 3 shows the changes in the concentration of lactulose and furosine, and LU/FU ratio as changing in the amounts of reconstituted milk added to fresh milk. The contents of lactulose and furosine greatly increased when raw milk was supplemented with reconstituted milk $(p<0.05)$. Although both the contents of lactulose and furosine increased, the increase rate of lactulose was much lower than that of furosine. When $10 \%$ reconstituted milk was added to raw milk, the lactulose content was about 5 times higher than that of raw milk, whereas furosine was more than 10 times higher. Moreover, when additional reconstituted milk was added to raw milk, furosine showed a relatively proportional increase while the lactulose contents were not much increased. According to Pellegrino et al. (1995), high concentrations of furosine are formed during the production of milk powder because the $\mathrm{a}_{\mathrm{w}}$ values reached during drying are optimal for the Maillard reaction. Mortier et al. (2000) also mentioned that addition of reconstituted milk during the production of market milk will lead to abnormally high furosine values for pasteurized milk.

The LU/FU ratio is another thermal index used to assess the heat treatment of milk, and it is used to identify reconstituted milk added to fresh milk (Guerra-Hernandez et al., 2002; Lan et al., 2010; Pellegrino et al., 1995). Compared with the raw milk having a LU/FU ratio of 4.3, the LU/FU ratios of the milk samples supplemented with reconstituted milk were lower than 2.0 (Table 3). There was more than twice the reduction in LU/FU ratios after the addition of reconstituted milk. As mentioned above, the increase of furosine was much higher than that of

Table 3. Changes in concentrations of lactulose and furosine, and $L U / F U$ ratio by addition of reconstituted milk

\begin{tabular}{cccc}
\hline \hline $\begin{array}{c}\text { Added } \\
\text { amount }(\%)\end{array}$ & $\begin{array}{c}\text { Lactulose } \\
(\mathrm{mg} / 100 \mathrm{~mL})\end{array}$ & $\begin{array}{c}\text { Furosine } \\
(\mathrm{mg} / 100 \mathrm{~mL})\end{array}$ & $\mathrm{LU} / \mathrm{FU}^{2)}$ \\
\hline 0 & $1.524 \pm 0.087$ & $0.3514 \pm 0.0513$ & $4.377^{\mathrm{a}}$ \\
10 & $7.211 \pm 0.432$ & $4.0260 \pm 0.4918$ & $1.791^{\mathrm{bc}}$ \\
20 & $10.350 \pm 0.296$ & $6.1458 \pm 0.3434$ & $1.684^{\mathrm{bc}}$ \\
30 & $10.573 \pm 0.293$ & $8.3287 \pm 0.5394$ & $1.269^{\mathrm{c}}$ \\
\hline
\end{tabular}

\footnotetext{
${ }^{1)}$ All values are mean \pm SD of three replicates.

${ }^{\mathrm{a}-\mathrm{d}}$ Means within a column with the same letter are not significantly different $(p<0.05)$.
}

lactulose, giving rise to a decrease of LU/FU ratio. Lan et al., (2010) also showed that LU/FU ratio of raw milk, which was greater than 1.0 reduced by half after heat treatment and addition of reconstituted milk.

As a result, furosine content and the LU/FU ratio may serve as a potential indicator in evaluation of heat treatment and to determine the addition of reconstituted milk to raw milk.

\section{Conclusion}

During heat treatment and storage of milk, formation of lactulose and furosine in different concentrations was observed because the lactose isomerization and early Maillard reaction have different kinetics and are affected differently by milk composition. Nevertheless, the correlation between these two variables in such different reaction mechanisms indicated that they both reflected the same phenomenon. Lactulose already has been proposed by the IDF (1992) as an official analytical indicator of differentiating between UHT milk and in-bottle sterilized milk. By contrast, furosine concentration has not been proposed; however, results in this study suggested that furosine might also be a precise indicator of heat treatment in milk. Application of observed LU/FU ratio in samples would allow the detection of improper addition of reconstituted milk in commercial milk.

\section{Acknowledgement}

The present research was conducted with research funds from Dankook University in 2009.

\section{References}

1. Akalin, A. S. and Gonc, S. (1997) Lactulose and 5-HMF contents in market milks. Milchwissenschaft 52, 377-379.

2. Andrews, G. (1984) Distinguishing pasteurized, UHT and sterilized milks by their lactulose content. J. Soc. Dairy Tech. 37, 92-95.

3. Corzo, N., Delgado, T., Troyano, E., and Olano, A. (1994) Ratio of lactulose to furosine as indicator of quality of commercial milks. J. Food Prot. 57, 737-739.

4. De Block, J., Merchiers, M., Van Renterghem, R., and Moermans, R. (1996) Evaluation of two methods for the determination of lactulose in milk. Int. Dairy J. 6, 217-222.

5. De Rafael, D., Villamiel, M., and Olano, A. (1997) Formation of lactulose and furosine during heat treatment of milk at temperatures of $100-120^{\circ} \mathrm{C}$. Milchwissenschaft 52, 76-78.

6. Delgado, T., Corzo, N., Santa-Maria, G., Jimeno, M. L., and Olano. A. (1992) Determination of furosine in milk samples 
by ion-pair reversed phase liquid chromatography. Chromatographia 33, 374-376.

7. Guerra-Hernandez, E., and Corzo, N. (1996) Furosine determination in baby cereals by ion-pair reversed-phase liquid chromatography. Anal. Tech. Instrument. 73, 729-731.

8. Guerra-Hernandez, E., Corzo, N., and Garcia-Villannova, B. (1999) Maillard reaction evaluation by furosine determination during infant cereal processing. J. Cereal Sci. 29, 171176.

9. Guerra-Hernandez, E., Leon, C., Corzo, N., Garcia-Villannova, B., and Romera, J. M. (2002) Chemical changes in powdered infant formulas during storage. Int. J. Dairy Technol. 55, 171-176.

10. Hewedy, M., Kiesner, M. C., Meissner, K., Hartkopf, J., and Erbersdobler, H. F. (1994) Effects of UHT heating of milk in an experimental plant on several indicators of heat treatment. J. Dairy. Res. 61, 305-308.

11. Hurrell, R. F., and Finot, P. A. (1983) Storage of milk powders under adverse conditions. Br. J. Nutr. 49, 343-354.

12. IDF (1991) Heat treated milk Determination of lactulose content: High performance liquid chromatography (reference method) Bulletin of the International Dairy federation 147/1991, Brussels, pp. 621-623

13. IDF (1992) Influence of technology on the quality of heat treated milk and fluid milk products. Bulletin of the International Dairy federation, B-Doc. 222, Brussels.

14. Kulmyrzaev, A. and Dufour, E. (2002) Determination of lactulose and furosine in milk using front-face fluorescence spectroscopy. Lait 82, 725-735

15. Lan, X. Y., Wang, J. Q., BU, D. P., Shen, J. S., Zheng, N., and
Sun, P. (2010) Effects of heating temperatures and addition of reconstituted milk on the heat indicators in milk. J. Food Sci. 75, C653-C658.

16. Marconi, E., Messia, M.C., Amine, A., Moscone, D., Vernazza, F., Stocchi, F., and Palleschi, G. (2004) Heat-treated milk differentiation by a sensitive lactulose assay. Food Chem. 84, 447-450.

17. Montilla, A., Calvo, M., Santa-maria, G., Gorzo, N., and Olano, A. (1996) Correlation between lactulose and furosine in UHT-heated milk. J. Food Prot. 59, 1061-1064.

18. Montilla, A. and Olano, A. (1997) Effect of the protein content and dilution on the lactulose/furosine ratio in heat-treated milk. Milchwissenschaft 52, 506-507.

19. Mortier, L., Braekman, A., Caltuyvels, D., Van Renterghem, R., and De block, J. (2000) Intrinsic indicators for monitoring heat damage of consumption milk. Biotechnol. Agron. Soc. Environ. 4, 221-225.

20. Pellegrino, L. (1994) Influence of fat content on some heatinduced changes in milk and cream. Neth. Milk Dairy J. 48, 71-80.

21. Pellegrino, L., De Noni, I., and Resmini, P. (1995) Coupling of lactulose and furosine indices for quality evaluation of sterilized milk. Int. Dairy J. 5, 647-659.

22. Resmini, P. and Pellegrino, L. (1994) HPLC of furosine in for evaluating Maillard reaction damage in skimmilk powders during processing and storage. Bulletin of the International Dairy federation 298/1994. Brussels, pp. 31-36.

(Received 2012.5.9/Revised 2012.8.17/Accepted 2012.8.24) 